DOI: 10.12731/wsd-2018-5-119-131

УДК 614.9:616.9

\title{
СОВРЕМЕННЫЕ МЕТОДЫ И ОПЫТ БОРЬБЫ С ЛЕЙКОЗОМ КРУПНОГО РОГАТОГО СКОТА
}

\author{
Зубова Т.В., Плешков В.А., Миронов А.Н.
}

В статье представлены основные методы диагностики и борьбы с вирусом лейкоза крупного рогатого скота используемые в настоящее время. Широкое распространение заболевания обусловлено достаточно легкой передачей вируса, отсутствием средств ранней диагностики, вакцинации и лечения. Поэтому проблема распространения вируса лейкоза крупного рогатого скота стоит очень остро и является актуальным вопросом в животноводстве, который требует скорейшего решения.

Цель работы заключалась в оздоровлении стада крупного рогатого скота от вируса лейкоза путем проведения комплекса мероприятий. Исследования проводились в крестьянско-фермерском хозяйстве индивидуального предпринимателя В.Д. Зинченко Кемеровской области на скоте черно-пестрой породы. Мероприятия по борьбе с ВЛКРС заключались в выявлении больных и инфицированных животных при проведении плановых диагностических исследований и дальнейтее их исключение из стада.

Результаты исследования показали положительную динамику освобождения стада от вируса лейкоза. Отдельное содержание РИД+ животных, изолированное выращивание нетелей (из числа потомства от больных и инфицированных коров) для поэтапной их замены и дальнейшее включение в здоровое стадо, дает значительное снижение числа вирусоносителей и больных животных.

Ключевые слова: инфекционная опасность; лейкоз крупного рогатого скота; больные коровы; борьба с лейкозом КРС; методы диагностики лейкоза КРC.

\section{MODERN METHODS AND EXPERIENCE OF STRUGGLE AGAINST LEUKEMIA OF CATTLE}

\author{
Zubova T.V., Pleshkov V.A., Mironov A.N.
}

The article presents the main methods of diagnosis and control of the bovine leukemia virus currently used. The wide spread of the disease is due to a fairly 
easy transmission of the virus, the lack of early diagnosis, vaccination and treatment. Therefore, the problem of the spread of leukemia virus in cattle is very acute and is a pressing issue in animal husbandry, which requires a speedy solution.

The purpose of the work was to improve the herd of cattle from leukemia virus through a set of measures. The studies were conducted in the peasant farm individual entrepreneur V.D. Zinchenko of the Kemerovo region on the blackand-white cattle. Measures to combat VLKRS consisted in the identification of sick and infected animals during routine diagnostic studies and their further exclusion from the herd.

The results of the study showed a positive trend in the release of the herd from leukemia virus. Separate content of RID + animals, isolated breeding of heifers (from the number of offspring from sick and infected cows) for their phased replacement and further inclusion in a healthy herd, gives a significant reduction in the number of virus carriers and sick animals.

Keywords: risk of infection; bovine leukemia; sick cows; fight against leukemia in cattle; diagnostic methods; bovine leukemia.

В Российской Федерации скотоводство является главным поставщиком продукции животноводства, способное обеспечить продовольственную безопасность населения без зависимости от других стран.

Для интенсивного развития животноводства необходимо формирование высокопродуктивного здорового поголовья скота. Одной из болезней препятствующей развитию и наносящей большой ущерб скотоводству является практически повсеместное распространение вируса лейкоза крупного рогатого скота (ВЛКРС).

Лейкоз крупного рогатого скота - хроническое вирусное заболевание, характеризующееся злокачественным поражением органов лимфоидной и кроветворной систем, и относящееся к одной из наиболее опасных и распространенных заболеваний крупного рогатого скота. Лейкоз регистрируют практически во всех странах мира, за исключением некоторых стран Западной Европы, где его ликвидировали только путем полного уничтожения инфицированных животных. Наиболее широко эта болезнь распространена в США, Канаде, Японии, и ряде стран Европы. Среди протестированных животных 83,9\% поголовья молочных стад в США оказались серопозитивны в отношении BLV, для Канады этот показатель составил 89\%, для Аргентины - 84\%, Японии - 68\%; в Бразилии и Южной Америке уровень инфицированности КРС вирусом лейкоза составляет 50\%, в странах Средней Азии - около 20\% [3, 6, 11, 20, 22]. 
В Российской Федерации проблема распространения вируса лейкоза крупного рогатого скота стоит очень остро и является актуальным вопросом, требующим безотлагательного решения, так как состояние животноводческих хозяйств в большинстве регионов страны по этому заболеванию неблагополучно.

Так, по данным Департамента ветеринарии Министерства сельского хозяйства Российской Федерации [9] «...Лейкоз крупного рогатого скота в 2017 году регистрирован в 67 субъектах Российской Федерации (в 2016 году - в 68 субъектах).

Улучшилась эпизоотическая ситуация по лейкозу крупного рогатого скота в Курской, Орловской, Тамбовской, Калининградской, Новгородской, Кировской, Нижегородской, Ульяновской, Свердловской, Иркутской областях, Удмуртской Республике, Красноярском крае. В этих субъектах уменьшилось количество неблагополучных пунктов и заболевших лейкозом животных.

Остаётся сложной эпизоотическая ситуация по лейкозу крупного рогатого скота в Новосибирской области - 222 неблагополучных пункта, Челябинской - 127 пунктов, Калужской - 109, Краснодарском крае - 100, Московской области - 92, Курганской - 87, Тверской - 74, Самарской 66 , Республике Татарстан - 62, Приморском крае - 62, Кемеровской области -58 , Тюменской -53 , Пензенской -53 и других субъектах...».

Обширное распространение лейкоза крупного рогатого скота обусловлено достаточно легкой передачей вируса, отсутствием средств ранней диагностики, вакцинации и лечения данного заболевания.

В то же время, диагностика должна обеспечивать оперативное выявление инфицированных животных и быть при этом простой и эффективной [5].

Выявление вирусоносителей представлено различными методами: реакция иммунодиффузии (РИД), иммуноферментный анализ (ИФА), полимеразная цепная реакция (ПЦР), гематологические, клинические, патоморфологические исследования и биопробы $[2,17]$.

Для диагностики лейкоза крупного рогатого скота сегодня в основном применяются серологические (РИД и ИФА) и гематологические методы исследования. В то же время повсеместно используемые методы диагностики не в состоянии обнаружить всех инфицированных животных по причине отсутствия, либо низкого уровня антител. Серологические тесты так же могут дать неоднозначный результат на ранних стадиях заболевания животных и могут возникнуть ложные положительные результаты [23].

Кроме того, эти методы не обеспечивают полного выявления инфицированных животных, так как телята до шести месячного возраста остают- 
ся в неплановых исследований, из-за с отсутствия у них обнаруживаемого антителообразования.

В этом отношении весьма перспективным является молекулярно-генетический метод диагностики инфекции - полимеразная цепная реакция (ПЦР), который успешно используется в последние годы с целью выявления носителей ретровирусных инфекций для обнаружения провирусной ДНК, интегрированной в геном хозяина. Этот метод обладает максимальной чувствительностью и высокой специфичностью, что дает возможность обнаружения вируса в материале уже через 1-2 недели после заражения. Кроме того этот метод применим для молодняка старше 15 дневного возраста $[1,7,10,12]$.

В настоящее время в России решение проблемы ВЛКРС основывается на «Правилах по профилактике и борьбе с лейкозом крупного рогатого скота», утвержденных приказом Министерства сельского хозяйства и продовольствия Российской Федерации №359 от 11.05.1999 г. [18].

В соответствии с правилами искоренение лейкоза заключается в выбраковке больных животных и изоляции, инфицированных с последующей постепенной заменой их здоровыми. Все поголовье крупного рогатого скота, подлежит исследованию на лейкоз с шести месячного возраста по РИД-реакции и с двух летнего возраста - гематологические. Серологические исследования по РИД проводят в возрасте $6,12,16,18$ месяцев. Гематологические исследования взрослому поголовью (РИД положительному) каждые шесть месяцев.

Диагноз на лейкоз ставят, исходя из исследований крови на реакции иммунной диффузии (РИД), которая строго специфична. При установлении положительной реакции иммунной диффузии, животного изолируют и проводят гематологические исследования крови, которые заключаются в выявлении в периферической крови повышенного числа лейкоцитов, слабо дифференцированных клеток, а так же полиморфных атипичных клеток. При выявлении гематологических изменений в крови животных считают больными лейкозом [1].

Основными мероприятиями по искоренению лейкоза в Кемеровской области, в зависимости от степени поражения поголовья в хозяйствах, являются замена или убой инфицированных групп коров, ежеквартальное выделение и немедленный убой вирусоносителей и ГЕМ больных животных.

Мероприятия по борьбе с лейкозом крупного рогатого скота на территории Кемеровской области проводятся в соответствии с: 
- Планом диагностических исследований, ветеринарно-профилактических и противоэпизоотических мероприятий в хозяйствах всех форм собственности;

- Правилами по профилактике и борьбе с лейкозом крупного рогатого скота, утвержденными приказом Министерства сельского хозяйства и продовольствия Российской Федерации от 11.05.1999 № 359 [18];

- Методическими указаниями по диагностике лейкоза крупного рогатого скота, утвержденными руководителем Департамента ветеринарии Министерства сельского хозяйства Российской Федерации 23.08.2000 № 13-7-2/2130.

Оздоровление хозяйств, независимо от форм собственности, осуществляется на основании приказов управления ветеринарии Кемеровской области «Об объявлении неблагополучия и установлении ограничений» № 247 от 14.09.2015 г., №11 от 05.02.2016 г., №12 от 05.02.2016 г., №8 от 03.02.2017 г., разработанных индивидуальных планов.

Как показывает статистика и анализ хозяйств по благополучию лейкоза у большинства животных инфицированных вирусом лейкоза крупного рогатого скота (около 70\%), заболевание протекает бессимптомно, в то же время приблизительно у $30 \%$ зараженных животных развивается легкая форма заболевания - персистентный лимфоцитоз. Дальнейшее развитие заболевания переходящее в летальную лимфосаркому возникает у инфицированных животных в пределах $5 \%$ от заболевших $[4,8,15,19,20,21]$.

Не смотря на всю опасность заболевания, и его достаточно легкой передачи между животными, выявлено, что более $80 \%$ телят от инфицированных коров, рождаются свободными от вируса лейкоза. Это связано с тем, что только в $10-15 \%$ случаев, вирус преодолевает интраплацентарный барьер матери, инфицируя плод. Следовательно, при многогранном и компетентном подходе к проблеме заболевания за несколько лет путем выращивания достаточного количества свободных от вируса нетелей возможно полностью обновить неблагополучное стадо, не прибегая к закупке дорогостоящих племенных животных $[13,14]$.

Тем не менее, располагая информацией о характере заболевания и путях его распространения, одним из более доступных и возможных способов оздоровления хозяйств является выявлении больных и инфицированных животных при проведении диагностических исследований и дальнейшее их исключение из стада.

Таким образом, строгое соблюдение: «Правил по профилактике и борьбе с лейкозом крупного рогатого скота», утвержденных 11.05.1999 г. 
[18]; мероприятий по борьбе с лейкозом крупного рогатого скота проводимыми на территории Кемеровской области в соответствии с ежегодными планами диагностических исследований, ветеринарно-профилактических и противоэпизоотических мероприятий в хозяйствах всех форм собственности; индивидуальных планов хозяйств всех форм собственности и своевременное проведение всего комплекса противолейкозных мероприятий, в хозяйствах, может создать благоприятную ситуацию по заболеваемости поголовья, позволяя без единовременной ликвидации поголовья получать продукцию и сохранять потомство для дальнейшего введения в стадо.

Для искоренения лейкоза требуется активное участие как ветеринарной службы, так владельцев животных. При этом важнейшую роль играют организационно-хозяйственные и административные мероприятия по профилактике и борьбе с лейкозом.

Формирование иелей и задачи исследования. Объектом исследования служили здоровые, серопозитивные (РИД +) и больные лейкозом коровы черно-пестрой породы КФХ ИП Зинченко В.Д.

Анализ поголовья черно-пестрой породы КФХ ИП Зинченко В.Д. в Кемеровской области, показал положительную динамику освобождения стада от вируса лейкоза путем изолированного выращивания нетелей из числа потомства от больных и инфицированных коров для поэтапной их замены [14].

Проведение оздоровительных мероприятий проводили согласно разработанному «Плану мероприятий по профилактике и борьбе с лейкозом крупного рогатого скота на 2014-2019 годы в КФХ ИП Зинченко В.Д.» [16], который предусматривал выполнение определенных организационно-хозяйственных и ветеринарно-профилактических мероприятий.

В организационно-хозяйственном разделе плана определены мероприятия устанавливающие порядок продажи, сдачи на убой, выгон, размещение на пастбищах и все другие перемещения и перегруппировки животных; их четкую нумерацию и мечение; комплектование разных ферм РИД-положительными и РИД-отрицательными животными; формирование из нетелей отдельных групп и гуртов; не допускать нетелей в основное стадо коров; на ферме с РИД-отрицательными животными проводить только искусственное осеменение и другие работы.

В разделе плана ветеринарных мероприятий установлен порядок и сроки проведения гематологических и серологических исследований животных; организация отёлов здоровых и инфицированных коров; организация выпойки и выращивания молодняка и дезинфекции животноводческих помещений и убойных площадок. 
Изложение основного материала исследования. Благодаря раздельному содержанию неблагополучной группы животных на отдельной ферме и своевременному проведению диагностических исследований с целью выявления инфицированных и больных животных, удалось достичь определенного успеха в оздоровлении стада.

Неблагополучная группа животных размещается на ферме №1 в с. Сидоренково и состоит из коров, нетелей, телок в возрасте 6-16 месяцев и телят до 6 месяцев. Из этой фермы отбирают РИД - отрицательный молодняк для перевода в оздоравливаемое стадо на другую ферму.

Оздоравливаемое стадо находится на ферме №2 в с. Поморцево, и в данную группу входят РИД - отрицательные коровы, нетели и телки старше 6-месячного возраста. Это свободная от ВЛКРС ферма, которая постоянно пополняется серонегативными телками, после первого их исследования в 6-месячном возрасте.

Отмечается положительная динамика освобождения от вируса лейкоза, в общем, по КФХ ИП Зинченко В.Д. (табл. 1). Так, если в 2016 году по ферме в с. Сидоренково было обнаружено 199 РИД+ реагирующих голов (7\% от исследуемого поголовья), в 2017 году - 183 головы (8\% от исследуемого поголовья), то в 2018 году всего 64 головы (4,45\% от исследуемого поголовья). Гематологические исследования в эти годы позволили выявить 16 ( $2 \%$ от исследуемого поголовья) положительно реагирующих голов в 2016 году, 19 (3\% от исследуемого поголовья) голов в 2017 году, и всего 7 (0,86\% от исследуемого поголовья) положительно реагирующих голов в 2018 году.

Таблицуа 1.

Степень поражения поголовья по годам

\begin{tabular}{|c|c|c|c|c|c|c|c|}
\hline & \multirow{4}{*}{ Показатель } & \multicolumn{6}{|c|}{ Год } \\
\hline & & & & & & & \\
\hline & & & рма & & & Фе & рма \\
\hline & & №1 & №2 & №1 & №2 & №1 & №2 \\
\hline Всего голо & в хозяйстве & 1012 & 750 & 867 & 640 & 860 & 624 \\
\hline РИД & Всего исследовано, голов & 2799 & 2874 & 2280 & 1976 & 1435 & 1315 \\
\hline & $\begin{array}{l}\text { Положительно реагирую- } \\
\text { щих, голов }\end{array}$ & 199 & 48 & 183 & 14 & 64 & 18 \\
\hline & $\%$ & 7 & 1 & 8 & 0,7 & 4,45 & 1,36 \\
\hline Гематоло- & Всего исследовано, голов & 760 & 10 & 613 & 7 & 805 & 16 \\
\hline $\begin{array}{l}\text { гические } \\
\text { исследова- }\end{array}$ & $\begin{array}{l}\text { Положительно реагирую- } \\
\text { щих, голов }\end{array}$ & 16 & 0 & 19 & 0 & 7 & 0 \\
\hline & $\%$ & 2 & 0 & 3 & 0 & 0,86 & 0 \\
\hline
\end{tabular}


В оздоравливаемом стаде на ферме в с. Поморцево отмечается неоднозначная картина по освобождению поголовья от вируса лейкоза, поскольку в 2016 году было выявлено 48 РИД+ реагирующих голов (1\% от исследуемого поголовья), в 2017 году - 14 голов (0,7\% от исследуемого поголовья), но в 2018 году было выявлено 18 голов (1,36\% от исследуемого поголовья). Гематологические исследования поголовья за 2016-2018 годы не выявили ни одного положительно реагирующего животного.

Выводы исследования и перспективы дальнейших изысканий данного направления. Таким образом, планомерная работа по введению здорового поголовья и изолированное содержание РИД+ дает существенное снижения вновь выявленных вирусоносителей и больных животных.

Такая борьба с вирусом лейкоза в хозяйстве, хоть и показывает положительную динамику искоренения вирусоносителей и больных животных, но в свою очередь, так же имеет определенные трудности. Необходимо наличие свободных помещений для изоляции животных, специального рабочего персонала задействованного на работе только с чистым от вируса лейкоза поголовьем, а так же инвентаря и других средств содержания и обслуживания животных. Это несет дополнительную нагрузку на животноводческое хозяйство и экономические показатели производства продукции животноводства.

В свою очередь эти проблемы вызывают необходимость изыскивать современные научные пути решения оздоровления лейкозного поголовья. Поэтому разработка и совершенствование мероприятий по борьбе с лейкозом крупного рогатого скота является значимой и актуальной темой в животноводстве.

Статья подготовлена в рамках соглашения с Минобрнауки России № 05.607.21.0208 «Разработка технологии геномного редактирования для воспроизводства высокоченного племенного крупного рогатого скота молочного направления, устойчивого к вирусу лейкоза» уникальный идентификатор соглашения RFMEFI60718X0208.

\section{Список литературы}

1. Бобкова Г.Н. Лейкоз крупного рогатого скота / Г.Н. Бобкова, П.П. Шамаро, Т.А. Прудникова // Вестник Брянской ГСХА. 2011 . С. 42-48.

2. Виноградова И.В. и др. Геногеографические исследования вируса лейкоза крупного рогатого скота / И.В. Виноградова, Е.А. Гладырь, Н.В. Ковалюк, 
М.В. Петропавловский И.М. Донник, Л.К. Эрнст, Н.А. Зиновьева // Достижения науки и техники АПК. №10-2011. С. 34-37.

3. Гулюкин М.И. и др. Межвидовая передача вируса лейкоза крупного рогатого скота в эксперименте / М.И. Гулюкин, Н.Г. Козырева, Л.А. Иванова и др. // Вопросы вирусологии. 2015. том 60, №5. С. 32-37.

4. Гулюкин М.И. и др. Эпизоотическая ситуация по лейкозу крупного рогатого скота в товарных и племенных хозяйствах Российской Федерации за 2014-2015 годы / М.И. Гулюкин, И.И. Баранов, Л.А. Иванова и др. // Ветеринария и кормление. 2016. №4. С. 4-41.

5. Димов С.К. Эпизоотический процесс и противоэпизоотическая система / С.К. Димов // Актуальные проблемы ветеринарной медицины: сб.научн. тр. РАСХН. Сиб. отде. Новосибирск, 1998. С. 290-296.

6. Завершинская О.В. и др. Исследование эпизоотического процесса лейкоза КРС на территории Тамбовской области за период 1998-2011 гг. // О.В. Завершинская, С.А. Комиссаров, А.Н. Завершинский // Вестник ТГУ, т.18, вып.1. 2013. С. 447-450.

7. Зиннатов Ф.Ф. и др. Детекция и типизация вируса лейкоза крупного рогатого скота / Ф.Ф. Зиннатов, И.Р. Гибадулина, Н.З. Хазипов, Р.П. Тюрикова, Б.В. Камалов // Вятский медицинский вестник. 2007. № 4. С. 48-50.

8. Иванов О.В., Иванов О.Ю. Рекомендации по практической диагностике и оздоровлению стад крупного рогатого скота от лейкоза / О.В. Иванов, О.Ю. Иванова // Farm Animals, 2015. №1. С. 22-24.

9. Информация об эпизоотической ситуации по заразным экономически значимым болезням животных на территории Российской Федерации // Письмо Департамента ветеринарии Министерства сельского хозяйства РФ № 25/735 от 30 марта 2018 г. Режим доступа: http://agroportal2.garant. ru:81/SESSION/PILOT/main.htm (дата обращения 11.11.2018 год).

10. Косовский Г.Ю. Инфекционная опасность носителей провируса вируса бычьего лейкоза и ее оценка в связи с лейкоцитозом / Г.Ю. Косовский, В.И. Глазко, И.А. Андрейченко, С.Н. Ковальчук, Т.Т. Глазко // Сельскохозяйственная биология. 2016. том 51. № 4. С. 475-482.

11. Красникова Е.С., Ларионова О.С., Красников А.В., Казиева Г.Х. Молоко-сырье от коров, инфицированных возбудителями ретровирусных инфекций крупного рогатого скота: вопросы безопасности и качества вырабатываемой продукции // Вопр. питания. 2018. Т. 87, № 4. С. 48-55.

12. Крюков В.И. и др. ДНК-диагностика в селекции крупного рогатого скота / В.И. Крюков, О.А. Шалимова, Н.Г. Друшляк, А.В. Пикунова // Вестник ОрелГАУ: Научное обеспечение животноводства. 2012. № 1. С. 62-68. 
13. Мальцева Н.А. и др. Лейкоз крупного рогатого скота - пути решения проблемы / Н.А. Мальцева, В.И. Баранов, Е.И. Олийник, А.А. Животов // Электронный журнал «Исследовано в России». 2000. С. 1376-1380. Режим доступа: http://elibrary.lt/resursai/Uzsienio\%20leidiniai/MFTI/2000/102.pdf (дата обращения 12.11.2018 года).

14. Новосельцев Г.Г. и др. Эффективный и безущербный метод борьбы с лейкозом крупного рогатого скота / Г.Г. Новосельцев, Карабактян В.А., Симонян Г.А., Репникова Н.В. // Сайт Департамента ветеринарии Краснодарского края. Режим доступа: http://www.kubanvet.ru/journal_n1_20113.html (дата обращения 11.11.2018 г.).

15. Особо опасные болезни животных: справочник / И.А. Бакулов, В.М. Котляров, А.С. Донченко [и др.]. Покров; Новосибирск, 2002. 184 с.

16. План мероприятий по профилактике и борьбе с лейкозом крупного рогатого скота на 2014-2019 годы в КФХ ИП Зинченко В.Д.

17. Пономаренко Д. Особенности диагностики и клинико-иммунологического проявления лейкоза крупного рогатого скота / Пономаренко Д., Абакин С., Калашникова Е. // Ветеринария сельскохозяйственных животных. 2011. № 9. C. 20-24.

18. Правила по профилактике и борьбе с лейкозом крупного рогатого скота, утвержденные приказом Министерства сельского хозяйства и продовольствия Российской Федерации №359 от 11.05.1999 г.

19. Проблемы лейкоза животных / П.Н. Смирнов, В.В. Незавитин, В.В. Смирнов и др. Новосибирск: Советская Сибирь, 1992. 479 с.

20. Рудакова О.Н. Анализ современных методов диагностики и ветеринарно-санитарная экспертиза мяса при лейкозе крупного рогатого скота / Диссертация на соискание ученой степени кандидата биологических наук: 06.02.05 - ветеринарная санитария, экология, зоогигиена и ветеринарно-санитарная экспертиза. Москва, 2010. 141 с.

21. Симонян Г.А. Ветеринарная гематология / Г.А. Симонян, Ф.Ф. Хисамутдинов. М.: Колос, 1995. 256 с.

22. Стегний Б.Т. и др. Современные аспекты лейкоза крупного рогатого скота / Б.Т. Стрегний, О.В. Шаповалова, С.К. Горбатенко, А.Н. Корнейков, В.М. Горжеев // Ветеринарна медицина. 2013. Вып. 97. С. 242-255. Режим доступа: http://www.jvm.kharkov.ua/sbornik/97/3_97.pdf (дата обращения 12.11.2018 г.).

23. Чижова Л.Н. Использование полимеразной цепной реакции в диагностике лейкоза КРС / Л.Н.Чижова, Д.Е. Белов // Сборник научных трудов Ставропольского научно-исследовательского института животноводства и кормопроизводства. 2004. Т. 2. № 2-2. С. 65-69. 


\section{References}

1. Bobkova G.N., Shamaro P.P., Prudnikova T.A. Vestnik Bryanskoy GSKhA. 2011, pp. $42-48$.

2. Vinogradova I.V., Gladyr E.A., Kovalyuk N.V., Petropavlovskiy M.V., Donnik I.M., Ernst L.K., Zinov'eva N.A. Dostizheniya nauki i tekhniki APK. №10-2011, pp. 34-37.

3. Gulyukin M.I., Kozyreva N.G., Ivanova L.A. et al. Voprosy virusologii. 2015. V. 60, №5, pp. 32-37.

4. Gulyukin M.I., Baranov I.I., Ivanova L.A. et al. Veterinariya i kormlenie. 2016. №4, pp. 4-41.

5. Dimov S.K. Aktual'nye problemy veterinarnoy meditsiny: sb. nauchn. tr. RASKhN [Actual problems of veterinary medicine: collection of scientific papers]. Sib. otde. Novosibirsk, 1998, pp. 290-296.

6. Zavershinskaya O.V., Komissarov S.A., Zavershinskiy A.N. Vestnik TGU, V.18, №1. 2013, pp. 447-450.

7. Zinnatov F.F., Gibadulina I.R., Khazipov N.Z., Tyurikova R.P., Kamalov B.V. Vyatskiy meditsinskiy vestnik. 2007. № 4, pp. 48-50.

8. Ivanov O.V., Ivanov O.Yu. Farm Animals, 2015. №1, pp. 22-24.

9. Pis'mo Departamenta veterinarii Ministerstva sel'skogo khozyaystva RF № 25/735 ot 30 marta 2018 [Letter of the Veterinary Department of the Ministry of Agriculture of the Russian Federation No. 25/735 of March 30, 2018]. http://agroportal2.garant.ru:81/SESSION/PILOT/main.htm

10. Kosovskiy G.Yu., Glazko V.I., Andreychenko I.A., Koval'chuk S.N., Glazko T.T. Sel'skokhozyaystvennaya biologiya. 2016. V. 51. № 4, pp. 475-482.

11. Krasnikova E.S., Larionova O.S., Krasnikov A.V., Kazieva G.Kh. Vopr. pitaniya. 2018. T. 87, № 4, pp. 48-55.

12. Kryukov V.I., Shalimova O.A., Drushlyak N.G., Pikunova A.V. Vestnik OrelGAU: Nauchnoe obespechenie zhivotnovodstva. 2012. № 1, pp. 62-68.

13. Mal'tseva N.A., Baranov V.I., Oliynik E.I., Zhivotov A.A. Issledovano v Rossii. 2000, pp. 1376-1380. http://elibrary.lt/resursai/Uzsienio\%20leidiniai/MF $\mathrm{TI} / 2000 / 102 . p d f$

14. Novosel'tsev G.G., Karabaktyan V.A., Simonyan G.A., Repnikova N.V. Sayt Departamenta veterinarii Krasnodarskogo kraya [Site of the Department of Veterinary Krasnodar Territory]. http://www.kubanvet.ru/journal_n1_20113. html

15. Osobo opasnye bolezni zhivotnykh: spravochnik [Particularly dangerous animal diseases: a handbook] / I.A. Bakulov, V.M. Kotlyarov, A.S. Donchenko [i dr.]. Pokrov; Novosibirsk, 2002. 184 p. 
16. Plan meropriyatiy po profilaktike i bor'be s leykozom krupnogo rogatogo skota na 2014-2019 gody v KFKh. IP Zinchenko V.D. [The action plan for the prevention and control of cattle leukemia for 2014-2019 in KFH]

17. Ponomarenko D., Abakin S., Kalashnikova E. Veterinariya sel'skokhozyaystvennykh zhivotnykh. 2011. № 9, pp. 20-24.

18. Pravila po profilaktike i bor'be s leykozom krupnogo rogatogo skota, utverzhdennye prikazom Ministerstva sel'skogo khozyaystva i prodovol'stviya Rossiyskoy Federatsii №359 ot 11.05.1999 [Rules for the prevention and control of bovine leukemia, approved by order of the Ministry of Agriculture and Food of the Russian Federation No. 359 of 11.05.1999].

19. Problemy leykoza zhivotnykh [Problems of animal leukemia] / P.N. Smirnov, V.V. Nezavitin, V.V. Smirnov et al. Novosibirsk: Sovetskaya Sibir', 1992. 479 p.

20. Rudakova O.N. Analiz sovremennykh metodov diagnostiki $i$ veterinarno-sanitarnaya ekspertiza myasa pri leykoze krupnogo rogatogo skota [Analysis of modern methods of diagnosis and veterinary-sanitary examination of meat in cattle leukemia]. Moscow, 2010. 141 p.

21. Simonyan G.A., Khisamutdinov F.F. Veterinarnaya gematologiya [Veterinary Hematology]. M.: Kolos, 1995. 256 p.

22. Stegniy B.T., Shapovalova O.V., Gorbatenko S.K., Korneykov A.N., Gorzheev V.M. Veterinarna meditsina. 2013. Issue 97, pp. 242-255. http://www.jvm.kharkov.ua/sbornik/97/3_97.pdf

23. Chizhova L.N., Belov D.E. Sbornik nauchnykh trudov Stavropol'skogo nauchno-issledovatel'skogo instituta zhivotnovodstva i kormoproizvodstva [The use of polymerase chain reaction in the diagnosis of cattle leukemia]. 2004. V. 2. № 2-2, pp. 65-69.

\section{ДАННЫЕ ОБ АВТОРАХ}

Зубова Татьяна Владимировна, доцент кафедры зоотехнии, доктор биологических наук ФГБОУ ВО «Кемеровский государственный сельскохозяйственньй институт»

ул. Марковиева, 5, г. Кемерово, 650056, Российская Федерация suta54@mail.ru

Плешков Владимир Александрович, доцент кафедры селекции и генетики в животноводстве, кандидат сельскохозяйственных наук ФГБОУ ВО «Кемеровский государственный сельскохозяйственный институт» 
ул. Марковиева, 5, г. Кемерово, 650056, Российская Федераиция 6110699@mail.ru

\section{Миронов Александр Николаевич, начальник}

ГБУ КО «Беловская станция по борьбе с болезнями животных» ул. Пролетарская, 130, г. Белово, 652600, Российская Федерация vetbelovo@bk.ru

\section{DATA ABOUT THE AUTHORS}

Zubova Tatyana Vladimirovna, Associate Professor of Zootechnics, Doctor of Biological Sciences

Kemerovo State Agricultural Institute

5, Markovtseva Str., Kemerovo, 650056, Russian Federation suta54@mail.ru

Pleshkov Vladimir Alexandrovich, Associate Professor of Breeding and Genetics in Animal Husbandry, Candidate of Agricultural Sciences Kemerovo State Agricultural Institute 5, Markovtseva Str., Kemerovo, 650056, Russian Federation 6110699@mail.ru

Mironov Alexander Nikolaevich, Chief Animal Disease Station, Belovo, Russia 130, Proletarskaya Str., Belovo, 652600, Russian Federation vetbelovo@bk.ru 